OPEN ACCESS

Edited by:

Attila Mócsai,

Semmelweis University, Hungary

Reviewed by:

Marian Dmochowski,

Poznan University of Medical

Sciences, Poland

Teruki Dainichi,

Kyoto University, Japan

*Correspondence:

Dimitra Kiritsi

dimitra.kiritsi@uniklinik-freiburg.de

Specialty section:

This article was submitted to Autoimmune and Autoinflammatory

Disorders,

a section of the journal

Frontiers in Immunology

Received: 13 March 2019 Accepted: 20 December 2019

Published: 21 January 2020

Citation:

Schauer F, Ishii N, Mockenhaupt M,

Bruckner-Tuderman L, Hashimoto T and Kiritsi D (2020)

Radiation-Associated Pemphigus

Vulgaris in a Patient With Preceding Malignancy: Treatment With Rituximab as a Valuable Option

Front. Immunol. 10:3116. doi: 10.3389/fimmu.2019.03116

\section{Radiation-Associated Pemphigus Vulgaris in a Patient With Preceding Malignancy: Treatment With Rituximab as a Valuable Option}

\author{
Franziska Schauer ${ }^{1}$, Norito Ishii ${ }^{2,3}$, Maja Mockenhaupt ${ }^{1}$, Leena Bruckner-Tuderman ${ }^{1}$, \\ Takashi Hashimoto ${ }^{4}$ and Dimitra Kiritsi ${ }^{1 *}$ \\ ${ }^{1}$ Department of Dermatology, Medical Center - University of Freiburg, Faculty of Medicine, University of Freiburg, Freiburg, \\ Germany, ${ }^{2}$ Department of Dermatology, Kurume University School of Medicine, Kurume, Japan, ${ }^{3}$ Institute of Cutaneous Cell \\ Biology, Kurume University, Kurume, Japan, ${ }^{4}$ Department of Dermatology, Osaka City University Graduate School of \\ Medicine, Osaka, Japan
}

Pemphigus is a chronic autoimmune blistering disorder, characterized by (muco-)cutaneous erosions due to autoantibodies against desmoglein 3 and/or 1 . Pemphigus induction might be associated with drugs, malignancy or radiation therapy (RT); the latter being only rarely described. A rigorous literature review revealed around 30 cases of RT-associated pemphigus, which had been primarily treated with topical and/or systemic steroids, in some cases also dapsone or few other immunosuppressive agents were given. The most common underlying cancer type was breast cancer. We here present a 63-year-old male patient, who was pre-treated with adjuvant RT for larynx carcinoma 3 months before admission. He developed extensive cutaneous, ocular, and oral erosions. Despite the clinical picture comparable to a paraneoplastic pemphigus, the diagnosis of pemphigus vulgaris of mucocutaneous type was established based on the direct immunofluorescence, showing positive cell surface IgG and discrete C3 deposits, with matching cell surface IgG pattern on monkey esophagus. Serum autoantibodies to desmoglein 1 and 3 were highly positive. No further autoantibodies were found, thus paraneoplastic pemphigus was excluded. The patient was treated with high dose prednisolone, partially given intravenously up to $2 \mathrm{mg} / \mathrm{kg}$ per day, as well as topical disinfectants and class IV steroid cream. To stabilize the disease rituximab 2 $\times 1,000 \mathrm{mg}$ was given, leading to clinical and serological remission for up to 2 years now. We show that rituximab represents a good treatment option for the frequently treatment-refractory RT-associated pemphigus, a clinically and immunologically specific RT-induced skin disorder, resulting in long-term clinical, and serological remission.

Keywords: autoimmune blistering disorder, desmoglein, desmosome, desmosomal adhesion, radiation therapy

\section{INTRODUCTION}

The incidence of pemphigus has been estimated to be between 0.5 and 34 cases/million inhabitants/year (1), thus the disease is considered to be rare. As factors related to the induction of pemphigus, specific drugs and malignancy, but also radiation therapy (RT) have been proposed. Malignancy-associated pemphigus has an incidence of 5-11\%, while malignancy-associated bullous 
pemphigoid has a reported incidence of $5.8-10.2 \%$ in retrospective studies $(2,3)$. As the underlying malignancy, lung cancer was most common in pemphigus, and gastric cancer in bullous pemphigoid (3). Cases of RT-associated pemphigus have only rarely been described in the literature (Table 1). In this study, we report the development of pemphigus vulgaris (PV) in a patient who received RT for cancer treatment and review the literature on RT-associated pemphigus. Search terms included irradiation, radiation, radiotherapy, and cobalt therapy. The data provided include age, gender, underlying malignancy, dosage of RT, time intervals between RT and the onset of pemphigus, immunofluorescence data, and the treatment regime. In our patient we show that treatment with rituximab induces long-term clinical and serological remission for over two and a half years.

\section{METHODS}

\section{Immunofluorescence (IF) Studies}

Direct immunofluorescence (DIF) and indirect immunofluorescence (IIF) were performed in the Department of Dermatology, Medical Center-University of Freiburg. The FITC-labeled antibodies were anti-human IgG, IgA, IgM, and C3c (Dako, Hamburg, Germany) at a dilution of 1:200, 1:50, 1:50 and 1:500, respectively. For IIF on monkey esophagus, patients' sera were diluted 1:10; secondary antibodies used were FITC-labeled anti-human IgG (Dako, Hamburg, Germany) at a dilution of 1:100.

\section{Immunoblotting Studies}

Immunoblotting of normal human epidermal extracts $(31,32)$, the BP180 NC16a domain recombinant protein (33), the BP180 C-terminal domain recombinant protein (34), the concentrated culture supernatant of $\mathrm{HaCaT}$ cells (35), normal human dermal extract (36), and purified human laminin-332 for both IgG and/or IgA antibodies (37) were performed at the Kurume University and Osaka City University as previously described.

\section{Enzyme-Linked Immunosorbent Assays (ELISA) Studies}

Commercially available IgG ELISAs of Dsg1 and Dsg3 (MESACUP, MBL, Nagoya, Japan) were conducted according to the manufacturer's instructions and measured by ELISA reader.

\section{RESULTS}

We present a 63-year-old male patient, who was referred to our department due to extensive cutaneous (Figures 1A-C) and mucosal erosions (eyes, nose, lips, mouth, and esophagus). No paronychia-like or lichen planus-like lesions were observed. Until 3 months prior to admission, the patient had received adjuvant RT, following surgical reconstruction and bilateral neck lymph node dissection to treat larynx carcinoma. At that time point,

\footnotetext{
Abbreviations: DIF, direct immunofluorescence; HMGB1, High mobility group box 1; IIF, indirect immunofluorescence; ELISA, Enzyme-linked immunosorbent assay; PF, pemphigus foliaceus; PNP, paraneoplastic pemphigus; PV, pemphigus vulgaris; RAGE, receptor for advanced glycation endproduct; RT, radiation therapy.
}

the patient had received $54 \mathrm{~Gy}$ (single dose $1.8 \mathrm{~Gy}$ each) for his cervical right (level II-IV) and left region (III-IV), as well as a single boost at the tumor bed and additional 63.9 Gy (single dose 2.13 Gy each) for the left cervical lymph nodes (level II). The tumor appeared to be in remission. Histopathology of a skin specimen showed an intraepidermal split with the characteristic tombstone pattern of the basal keratinocytes (not shown). DIF of a skin specimen from the thigh revealed cell surface deposition of IgG (Figure 2A) and C3 in the entire epidermis. IIF with normal human skin and monkey esophagus (Figure 2B) revealed circulating cell surface IgG autoantibodies at a titer of 1:160. No reaction to the basement membrane zone or transitional epithelium of rat bladder was observed.

Immunoblotting of normal human epidermal extracts demonstrated IgG autoantibodies against the 130-kDa Dsg3 (Figure 2C, lane 4) (32), but no reactivity with Dsg1, envoplakin, periplakin, BP230, BP180, LAD-1 antigen, collagen VII, or laminin-332. Other immunoblotting methods did not detect any other autoantigens, including BP180, LAD-1 antigen, collagen VII, laminin gamma-1, and laminin-332. ELISA results were positive for both anti-Dsg1 (191 units; positive index $\geqq 20$ ), and anti-Dsg3 antibodies (144 units; positive index $\geqq 20$ ). ELISAs for recombinant eukaryotic desmocollin 1-3 proteins were negative (38). The discrepancy between immunoblotting and ELISA for anti-Dsg1 antibodies can be explained by that the PV sera tend to react with non-conformational epitopes, which are destroyed during the procedure of immunoblot, but not ELISA. The higher sensitivity in ELISA diagnostics has been well-established by previous studies (39). In fact it has been shown that in immunoblot with normal epidermal extracts most PV sera react with Dsg3, while only about two-thirds or PF sera react with Dsg1 (32). PV with underlying malignancy and PNP are sometimes difficult to distinguish. However, although our case had severe oral and ocular mucosal paraneoplastic pemphigus-like lesions, immunoblotting showed reactivity neither with envoplakin nor periplakin, excluding the diagnosis of PNP.

Initially, the patient was treated with high dose prednisolone, first given intravenously up to $2 \mathrm{mg} / \mathrm{kg}$ per day, topical disinfectants, and class IV steroid creams, combined with meticulous wound care for several weeks. Administration of rituximab $2 \times 1,000 \mathrm{mg}$ led to quick stabilization of the disease and to clinical and serological remission. Currently, the followup-time is two and a half years (Figure 1D), showing that rituximab is a valuable treatment for this rare pemphigus subtype; it improved the patient's quality of life tremendously.

A rigorous literature search for RT-associated pemphigus revealed 29 reported cases (Table 1). Of these, 23 represented $\mathrm{PV}$ and eight pemphigus foliaceus (PF). The age of the patients ranged from 37 to 92 years, with a median of 62 years. In 11 cases, the disease onset was within $<1$ month, in 12 cases skin lesions developed within the first 3 months after therapy initiation. Twenty-seven of 30 (90\%) cases initially presented with lesions at the irradiated side with the majority of these patients $(24 / 30$ cases, corresponding to $80 \%$ ) having a progression to the nonirradiated skin (11/24 cases, corresponding to $46 \%)$ or even to a generalized distribution (13/24 cases, corresponding to $54 \%$ ). 
TABLE 1 | Patients with radiation-associated pemphigus described in the literature.

\begin{tabular}{|c|c|c|c|c|c|c|c|c|c|c|}
\hline No & Age & Diagnosis & $\begin{array}{l}\text { Time from } \\
\text { radiation to start } \\
\text { of eruption }\end{array}$ & $\begin{array}{l}\text { DIF (cell } \\
\text { surface) }\end{array}$ & $\begin{array}{l}\text { IIF (cell } \\
\text { surface) }\end{array}$ & Neoplasm & $\begin{array}{l}\text { Radiation } \\
\text { characteristics }\end{array}$ & $\begin{array}{l}\text { Localization } \\
\text { (irradiated area, } \\
\text { non-irradiated area, } \\
\text { generalized) }\end{array}$ & Treatment & References \\
\hline 1 & 63 & PV & 1 month & $\lg G$ & $\lg G$ & $\begin{array}{l}\text { Hypopharynx } \\
\text { carcinoma }\end{array}$ & $\begin{array}{l}\text { LN cervical R II-IV, L III-IV } \\
54 \text { Gy, tumor bed, and LN } \\
\text { cervical II 63,9 Gy }\end{array}$ & $\begin{array}{l}\text { Irradiated area with generalized } \\
\text { progression }\end{array}$ & $\begin{array}{l}\text { Prednisolone } 2 \mathrm{mg} / \mathrm{kg} / \mathrm{day} \text {, } \\
\text { topical clobetasol propionate } \\
0.05 \% \text { ointment (body), } \\
\text { followed by rituximab } 2 \times \\
1,000 \mathrm{mg}\end{array}$ & Current case \\
\hline 2 & 48 & PV & 3 months & + & na & $\begin{array}{l}\text { Medullary breast } \\
\text { cancer }\end{array}$ & $100 \mathrm{~Gy}$ & $\begin{array}{l}\text { Irradiated area with progression } \\
\text { to non-irradiated area }\end{array}$ & Prednisone 150 mg/day & (4) \\
\hline 3 & 56 & PV & 1 year & na & na & $\begin{array}{l}\text { Epidermoid } \\
\text { bladder } \\
\text { carcinoma }\end{array}$ & 65 Gy & $\begin{array}{l}\text { Generalized mucocutaneous } \\
\text { type }\end{array}$ & Prednisone 60 mg/day & (5) \\
\hline 4 & 65 & PV & $<1$ month & na & na & Breast cancer & n.a & $\begin{array}{l}\text { Irradiated area with generalized } \\
\text { progression }\end{array}$ & $\begin{array}{l}\text { Prednisone } 80 \mathrm{mg} / \text { day, later } 120 \\
\mathrm{mg} / \text { day, methotrexate } 25 \mathrm{mg} \text {, } \\
\text { then azathioprine } 100 \mathrm{mg} / \text { day }\end{array}$ & (5) \\
\hline 5 & 70 & PV & 14 days & $\lg G, C 3$ & + & $\begin{array}{l}\text { Gastric } \\
\text { lymphosarcoma }\end{array}$ & 40 Gy & $\begin{array}{l}\text { Irradiated area with generalized } \\
\text { progression }\end{array}$ & Prednisone 120 mg/day & (6) \\
\hline 6 & 70 & PV & 4 months & + & + & $\begin{array}{l}\text { Solar keratosis } \\
\text { on the forehead }\end{array}$ & 48 Gy & $\begin{array}{l}\text { Irradiated area to non- irradiated } \\
\text { area }\end{array}$ & Prednisone 100 mg/day & (7) \\
\hline 7 & 52 & PV & 3 weeks & na & na & $\begin{array}{l}\text { Bronchial } \\
\text { squamous cell } \\
\text { carcinoma }\end{array}$ & 40 Gy & $\begin{array}{l}\text { Irradiated area with generalized } \\
\text { progression }\end{array}$ & $\begin{array}{l}\text { Methylprednisolone intravenously } \\
1,250 \mathrm{mg} 6 \text { days, then } 1 \mathrm{mg} / \mathrm{kg} \\
\text { BW and tapering } 45 \text { days }\end{array}$ & (8) \\
\hline 8 & 73 & PV & 3 months & + & + & Breast cancer & 55 Gy & $\begin{array}{l}\text { Irradiated area with generalized } \\
\text { progression }\end{array}$ & Prednisone 50 mg/day & (9) \\
\hline 9 & 70 & PF & 1 month & + & + & $\begin{array}{l}\text { Laryngeal } \\
\text { squamous cell } \\
\text { carcinoma }\end{array}$ & 60 Gy & $\begin{array}{l}\text { Irradiated area with progression } \\
\text { to non-irradiated area }\end{array}$ & $\begin{array}{l}\text { Prednisone } 2 \mathrm{mg} / \mathrm{kg} / \text { day, } \\
\text { azathioprine } 50 \mathrm{mg} / \text { day }\end{array}$ & (9) \\
\hline 10 & 54 & PV & 3 weeks & + & $\lg G$ & Lymphoma & 38 Gy & $\begin{array}{l}\text { Irradiated area with generalized } \\
\text { progression }\end{array}$ & Prednisone $2 \mathrm{mg} / \mathrm{kg} /$ day & (10) \\
\hline 11 & 77 & PV & na & + & + & $\begin{array}{l}\text { Basal cell } \\
\text { carcinoma }\end{array}$ & 60 Gy & $\begin{array}{l}\text { Irradiated area with progression } \\
\text { to non-irradiated }\end{array}$ & $\begin{array}{l}\text { Prednisone } 100 \text { mg/day, } \\
\text { dapsone } 100 \mathrm{mg} / \text { day }\end{array}$ & (11) \\
\hline 12 & 45 & PV & 1 week & + & na & Breast cancer & 68 Gy & Irradiated area & Prednisone 80 mg/day & (12) \\
\hline 13 & 61 & PV & 2 months & + & na & $\begin{array}{l}\text { SCC of the lower } \\
\text { lip }\end{array}$ & 70 Gy & $\begin{array}{l}\text { Irradiated area with progression } \\
\text { to non-irradiated }\end{array}$ & Prednisone $1 \mathrm{mg} / \mathrm{kg} /$ day & (13) \\
\hline 14 & 54 & PV & 1 month & $\lg G, C 3$ & $\lg G$ & SCC of the lung & 59.4 Gy & $\begin{array}{l}\text { Irradiated area with progression } \\
\text { to non-irradiated }\end{array}$ & $\begin{array}{l}\text { Methylprednisolone } \\
\text { intravenously, then oral } \\
\text { prednisone }\end{array}$ & (14) \\
\hline 15 & 73 & PV & 3 weeks & + & na & $\begin{array}{l}\text { Epidermoid } \\
\text { carcinoma }\end{array}$ & 66 Gy & $\begin{array}{l}\text { Irradiated area with progression } \\
\text { to non-irradiated }\end{array}$ & $\begin{array}{l}\text { Prednisone } 1.5 \mathrm{mg} / \text { day, followed } \\
\text { by rituximab } 6 \times 375 \mathrm{mg} / \mathrm{m}^{2}\end{array}$ & (15) \\
\hline 16 & 49 & PV & 4 weeks & + & na & Breast cancer & 50 Gy & $\begin{array}{l}\text { Non-irradiated area (mouth and } \\
\text { esophagus) }\end{array}$ & $\begin{array}{l}\text { Prednisone } 60 \text { mg/day, } \\
\text { methotrexate } 15 \mathrm{mg} \text { weekly }\end{array}$ & (16) \\
\hline
\end{tabular}


TABLE 1 | Continued

\begin{tabular}{|c|c|c|c|c|c|c|c|c|c|c|}
\hline No & Age & Diagnosis & $\begin{array}{l}\text { Time from } \\
\text { radiation to start } \\
\text { of eruption }\end{array}$ & $\begin{array}{l}\text { DIF (cell } \\
\text { surface) }\end{array}$ & $\begin{array}{l}\text { IIF (cell } \\
\text { surface) }\end{array}$ & Neoplasm & $\begin{array}{l}\text { Radiation } \\
\text { characteristics }\end{array}$ & $\begin{array}{l}\text { Localization } \\
\text { (irradiated area, } \\
\text { non-irradiated area, } \\
\text { generalized) }\end{array}$ & $\begin{array}{l}\text { Treatment } \\
\text { AlBD }\end{array}$ & References \\
\hline 17 & 48 & PV & 6 months & na & + & $\begin{array}{l}\text { Breast cancer } \\
\text { (ductal } \\
\text { carcinoma in } \\
\text { situ) }\end{array}$ & $\begin{array}{l}\text { Megavoltage radiation } \\
\text { therapy-50 Gy }\end{array}$ & Irradiated area & $\begin{array}{l}\text { Prednisone } 100 \text { mg/day, topical } \\
\text { steroids }\end{array}$ & $(17)$ \\
\hline 18 & 61 & PV & 1 month & $\lg G, C 3$ & $\begin{array}{l}\lg G \\
\text { (rabbit } \\
\text { tongue) }\end{array}$ & $\begin{array}{l}\text { Epidermoid } \\
\text { carcinoma of the } \\
\text { piriform sinus }\end{array}$ & $\begin{array}{l}70 \text { Gy tumor bed, } 54 \text { Gy } \\
\text { cercical area }\end{array}$ & $\begin{array}{l}\text { Irradiated area with generalized } \\
\text { progression }\end{array}$ & $\begin{array}{l}\text { Methylprednisolone } 1 \mathrm{~g} \text {, followed } \\
\text { by oral prednisolone } 1.5 \mathrm{mg} / \mathrm{kg} / \\
\text { day }\end{array}$ & (18) \\
\hline 19 & 47 & PV & $\begin{array}{l}\text { Within days } \\
\text { (face), } 6 \\
\text { months body }\end{array}$ & C4 & $\lg G$ & $\begin{array}{l}\text { Acinic cell } \\
\text { carcinoma of the } \\
\text { parotid gland }\end{array}$ & 39, 6 Gy (cheek and chin) & $\begin{array}{l}\text { Irradiated area with generalized } \\
\text { progression }\end{array}$ & $\begin{array}{l}\text { Prednisolone } 1 \mathrm{mg} / \mathrm{kg} / \text { day, } \\
\text { azathioprine } 150 \mathrm{mg} / \text { day and } \\
\text { rituximab } 2 \times 375 \mathrm{mg} / \mathrm{m}^{2}\end{array}$ & (19) \\
\hline 20 & 58 & PV & 21 days & $\lg G, C 3$ & + & $\begin{array}{l}\text { Low grade } \\
\text { infiltrating ductal } \\
\text { carcinoma }\end{array}$ & $\begin{array}{l}\text { Tumor area } 65 \text { Gy, } \\
\text { subclavicular area ( } 46 \text { Gy), } \\
\text { right internal mammary } \\
\text { node chain ( } 50 \text { Gy) }\end{array}$ & $\begin{array}{l}\text { Irradiated area with progression } \\
\text { to non-irradiated area }\end{array}$ & $\begin{array}{l}\text { Prednisone } 2 \mathrm{mg} / \mathrm{kg} / \text { day, MMF } \\
2 \mathrm{~g} / \text { day }\end{array}$ & (20) \\
\hline 21 & 84 & PV & 8 months & $\lg G$ & $\lg G$ & Breast cancer & 60 Gy & Non-irradiated area (mouth) & $\begin{array}{l}\text { Topical clobetasol propionate } \\
\text { ointment, oral prednisolone } \\
1 \mathrm{mg} / \mathrm{kg} / \text { day, azathioprine } \\
2.5 \mathrm{mg} / \mathrm{kg} / \text { day }\end{array}$ & (21) \\
\hline 22 & 58 & PV & 14 months & $\lg G$ & + & $\begin{array}{l}\text { Breast cancer (in } \\
\text { situ ductal) }\end{array}$ & na & $\begin{array}{l}\text { Irradiated area with progression } \\
\text { to non-irradiated }\end{array}$ & $\begin{array}{l}\text { Prednisone } 60 \mathrm{mg} / \text { day, } \\
\text { azathioprine } 50 \text { mg/day }\end{array}$ & (22) \\
\hline 23 & 68 & PV & $<1$ month & + & na & Breast cancer & 40 Gy & $\begin{array}{l}\text { Irradiated area with generalized } \\
\text { progression }\end{array}$ & Prednisolone, MMF & (23) \\
\hline 24 & 37 & PF & $<1$ month & + & + & $\begin{array}{l}\text { Malignant } \\
\text { thymoma }\end{array}$ & 30 Gy & $\begin{array}{l}\text { Irradiated area with generalized } \\
\text { progression (after sun exposure) }\end{array}$ & $\begin{array}{l}\text { Methylprednisolone } 12 \mathrm{mg} \text {, } \\
\text { azathioprine } 50 \mathrm{mg} / \text { day, } \\
\text { dapsone } 100 \mathrm{mg} / \text { day }\end{array}$ & (24) \\
\hline 25 & 92 & PF & 3 months & + & na & $\begin{array}{l}\text { Breast cancer (in } \\
\text { situ intraductal) }\end{array}$ & $50,4 \mathrm{~Gy}$ & $\begin{array}{l}\text { Irradiated area with generalized } \\
\text { progression }\end{array}$ & na & (25) \\
\hline 26 & 70 & PF & 12 months & $\lg G, C 3$ & $\lg G$ & Breast cancer & 60 Gy & $\begin{array}{l}\text { Irradiated area with progression } \\
\text { to non-irradiated }\end{array}$ & $\begin{array}{l}\text { Dapsone } 100 \mathrm{mg} / \text { day, topical } \\
\text { clobetasol propionate ointment }\end{array}$ & (26) \\
\hline 27 & 59 & PF & 1 month & $\lg G, C 3$ & na & $\begin{array}{l}\text { Extramammary } \\
\text { Paget disease }\end{array}$ & 52.5 Gy & $\begin{array}{l}\text { Irradiated area with progression } \\
\text { to non-irradiated }\end{array}$ & Prednisolone $0.5 \mathrm{mg} / \mathrm{kg} /$ day & (27) \\
\hline 28 & 65 & PF & 2 months & $\lg G, C 3$ & na & Breast cancer & 50 Gy & Irradiated area & Prednisolone 30 mg/day & (28) \\
\hline 39 & 44 & PF & $<2$ months & $\begin{array}{l}\operatorname{lgG} \text { and } \\
\text { C3, focal } \\
\text { staining } \\
\text { C3d, and } \\
\text { C4d }\end{array}$ & na & Breast cancer & na & $\begin{array}{l}\text { Irradiated area with generalized } \\
\text { progression }\end{array}$ & $\begin{array}{l}\text { Oral prednisolone } 1 \mathrm{mg} / \mathrm{kg} / \text { day, } \\
\text { topical hydrocortisone } 2.5 \% \\
\text { ointment (face), clobetasol } \\
\text { propionate } 0.05 \% \text { ointment } \\
\text { (body), oral dapsone }\end{array}$ & (29) \\
\hline 30 & 66 & PF & 1 month & $\lg G, C 3$ & na & $\begin{array}{l}\text { Breast cancer } \\
\text { (ductal } \\
\text { carcinoma in } \\
\text { situ) }\end{array}$ & 50 Gy & $\begin{array}{l}\text { Irradiated area with generalized } \\
\text { progression }\end{array}$ & Oral triamcinolone 40 mg/day & (30) \\
\hline
\end{tabular}



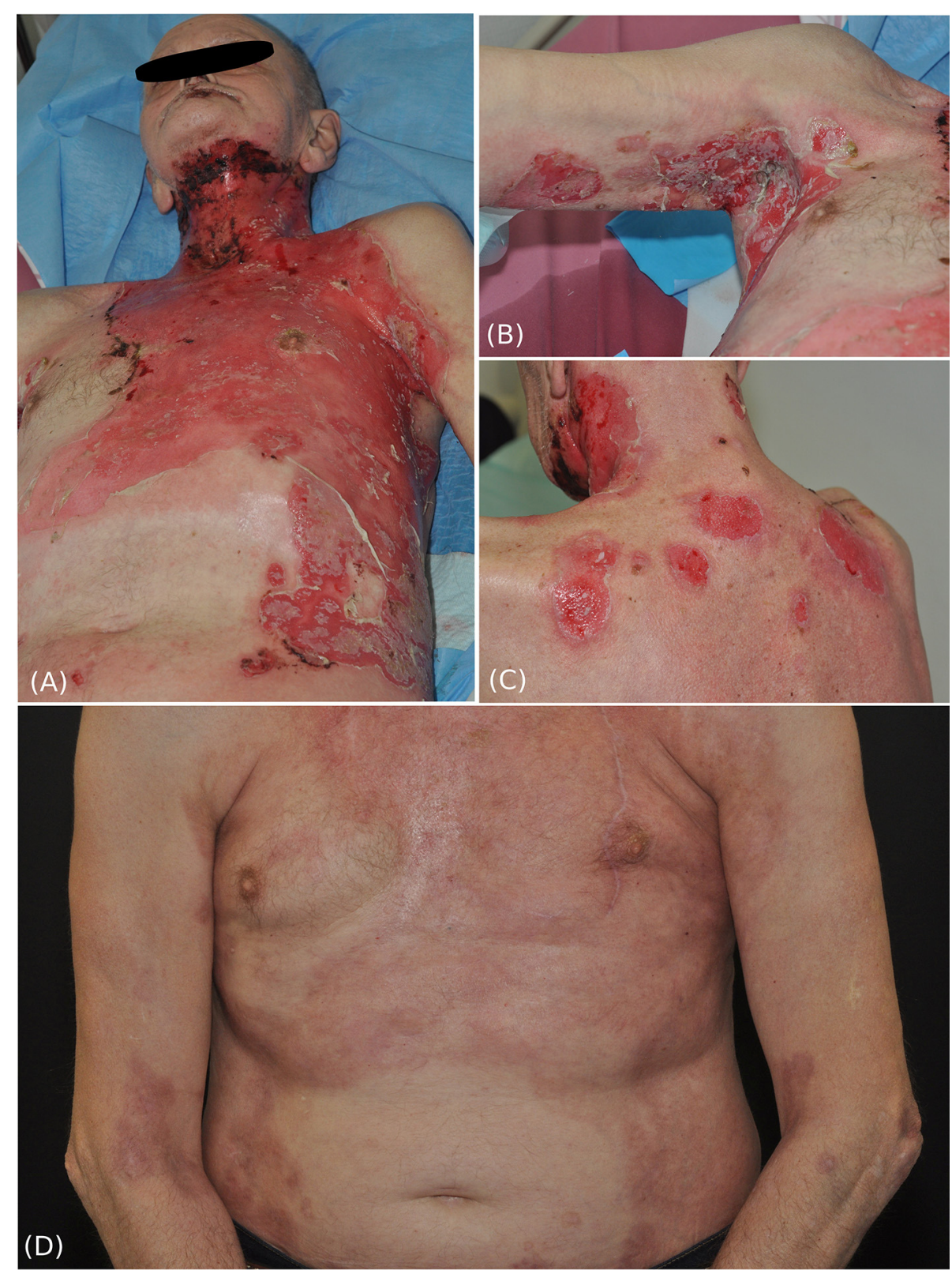

FIGURE 1 | Clinical pictures of the patient at initial presentation and after treatment. Extensive erosive skin detachment of the frontal trunk and neck (A), right axillary fold (B), and shoulders and neck (C). Three months after systemic treatment with rituximab and ongoing low dose glucocorticosteroids, intact skin with postinflammatory hyperpigmentations was observed (D).

The skin lesions stayed at the irradiation side in only three patients (3/30 cases, corresponding 10\%). Two patients developed erosions in the non-irradiated area at their first presentation, while one patient showed a generalized distribution pattern of PV. At least three cases (including ours) clinically imitated PNP. The pemphigus diagnosis was made in 20 cases by DIF, and in 14 of these cases additionally by IIF. ELISA was performed in only four cases. Fifteen patients $(n=9 \mathrm{PV}, n=6$ $\mathrm{PF}$ ) were treated for breast cancer. Others received radiotherapy for miscellaneous forms of cancer, for example lymphoma, gastric lymphosarcoma, squamous cell carcinoma of the skin or the lung, and bladder carcinoma. The RT dose varied from 38 to $100 \mathrm{~Gy}$, conducted in fractional application. All published patients, but one, have received oral, or intravenous glucocorticosteroids (prednisolone or methylprednisolone) in a medium to high dose. Ten individuals, representing one third of the reported, needed additional agents like dapsone, azathioprine or mycophenolate mofetil, at least temporarily. In two previously published cases 

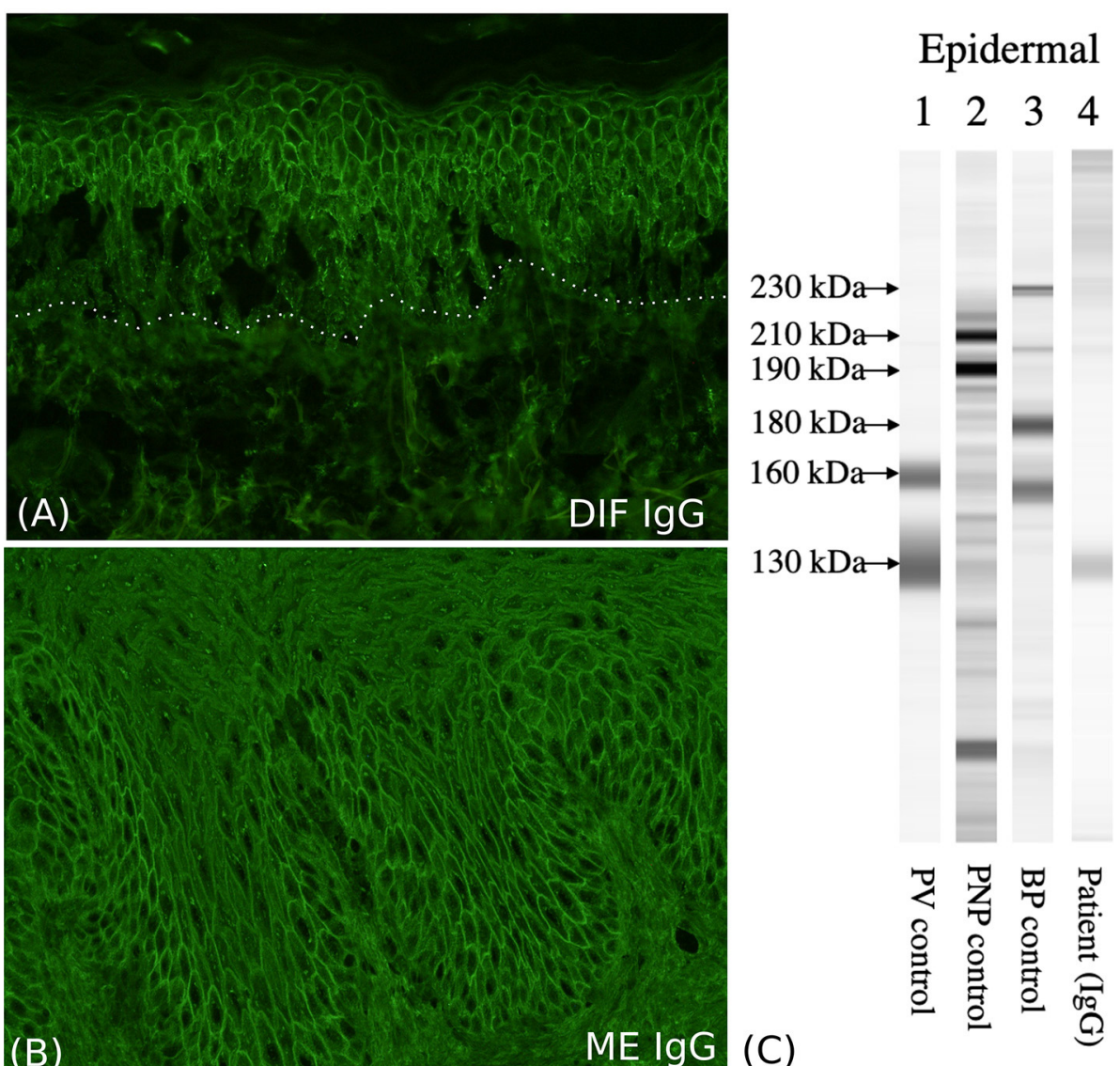

FIGURE 2 | Immunological characterization of the patient. (A) The direct immunofluorescence (DIF) shows cell surface IgG deposition on the keratinocytes of the entire epidermis. (B) Indirect immunofluorescence (IIF) with monkey esophagus (ME) shows circulating cell surface IgG autoantibodies. (C) Immunoblotting with normal human epidermal extracts shows IgG antibodies reactive with 130-kDa Dsg3 (lane 4).

rituximab had been given in different dosages $(2 \times 375$ and 6 $\times 375 \mathrm{mg} / \mathrm{m}^{2}$ ) and resulted in remission with a follow up of up to 6 months $(15,19)$. Three patients had a pre-existing PF (27-29) that aggravated during radiotherapy; suggesting that in patients with a history of an autoimmune blistering skin disorder, RT should be cautiously considered. Nevertheless, it is not an absolute contraindication, since patients with PV have tolerated radiation without exacerbation of the disease (40).

\section{DISCUSSION}

Here we report a severely affected patient with PV in whom RT for larynx cancer triggered the onset of the disease. So far, 29 cases RT-associated pemphigus have been reported in the literature with the majority of cases having lesions first at the RT site, soon followed by generalized erosions (Table 1). This clinical sign facilitates differentiation from a classical RTinduced dermatitis. In our case, high dose prednisolone and B-cell depletion by rituximab was required to induce clinical and serological remission for more than two and a half years, without need for further immunosuppression. Since this is the third case of RT-associated PV treated with rituximab, showing a quick response and resulting in clear remission in all three cases, we propose that rituximab should be considered early, when treating such patients. Rituximab selectively binds to CD20 and leads to B-cell depletion due to antibody- and complementdependent cytotoxicity, as well as induction of apoptosis. The use of immunosuppression in patients with malignancies should be avoided, whenever possible. However, in around one third of the already reported RT-associated pemphigus cases such drugs had to be given to control disease (Table 1). Thus, especially for the most severely affected patients, requiring additional immunosuppression than steroids, rituximab given at the already published regimen for PV (41) (1,000 mg rituximab on days 1 and 15) would be probably the most advantageous treatment option.

Another autoimmune skin blistering disorder that is pathogenetically often connected to malignancy or RT is bullous pemphigoid (BP). The so far published cases comprise similarly to RT-associated pemphigus more than 30 (42), including a stage IV melanoma patient with dual exposure to PD-1 
checkpoint inhibition and RT therapy (43). Nguyen et al. have summarized 29 patients with BP following radiation for malignancy treatment. BP was localized on the irradiated area in 25 of them, in two it was localized in non-irradiated sites and in another two it was generalized (44). All cases had a rather benign course, with corticosteroids being sufficient to control the disease. RT-associated pemphigus appears to have a more severe disease course, since it tends to spread to non-irradiated skin and in one third of cases further treatment with other immunosuppressants was required to control disease.

Several hypotheses have been proposed about the role of RT in induction of autoimmune skin blistering disorders. The efficacy and role of RT in anti-tumor therapy is believed to be due to the RT-induced DNA damage to malignant cells, but recent evidence demonstrates that RT also activates the innate immune system, promoting specific danger signals like complement, calreticulin, and high mobility group box 1 protein (HMGB1), as well as a variety of cytokines and chemokines (45). Beside a few patients who may have circulating autoantibodies before RT, the substantial role of complement in activation of BP is wellestablished, while the role of complement in pemphigus has a controversial standing (46). HMGB1, released by damaged cells can stimulate macrophages and dendritic cells, thus resulting in an activation of $\mathrm{T}$ cells. Increased serological concentration, paired with plentiful cytoplasmic overexpression of HMGB1 and its receptor RAGE has been observed in the epidermis of pemphigus patients (47). This results in tissue destruction and unmasking of epidermal structures, thus promoting autoreactivity in the irritated, immunocompromised area $(48,49)$. Furthermore, there are no sufficient data about the effects of RT damage and recovery of the thymus, which is in anatomical proximity to the tumor region in our patient. PostRT effects in total body RT mouse model comprised reduced thymocyte numbers and long-term suppression of thymopoesis (50), supporting a hypothesis of impaired T-cell education and disturbed selection processes inducing autoimmunity. Finally, RT-associated pemphigus appears to have a similar incidence as pemphigoid. This contrasts the situation in the nonradiated population, where $\mathrm{BP}$ is more common. That is another argument for the direct induction of autoantibodies by the tumor in the RT-associated pemphigus. Additional

\section{REFERENCES}

1. Jelti L, Cordel N, Gillibert A, Lacour J-P, Uthurriague C, Doutre $\mathrm{M}-\mathrm{S}$, et al. Incidence and mortality of pemphigus in France. J Invest Dermatol. (2019) 139:469-73. doi: 10.1016/j.jid.2018. 07.042

2. Iwashita K, Matsuyama T, Akasaka E, Mizutani K, Yamamoto K, Kondoh A, et al. The incidence of internal malignancies in autoimmune bullous diseases. Tokai J Exp Clin Med. (2007) 32:42-7.

3. Ogawa H, Sakuma M, Morioka S, Kitamura K, Sasai Y, Imamura S, Inaba Y. The incidence of internal malignancies in pemphigus and bullous pemphigoid in Japan. J Dermatol Sci. (1995) 9:136-41. doi: 10.1016/0923-1811(94) 00371-K

4. Lunder M. Una rara combinazione del pemfigo con cancro della mamella. Minerva Dermatol. (1973) 108:576-7. studies to characterize the pathogenesis of RT-associated pemphigus are required to gain a better understanding of the disease.

Taken together, we show that rituximab represents a good treatment option for the frequently treatment-refractory RT-associated pemphigus, resulting in long-term clinical, and serological remission.

\section{DATA AVAILABILITY STATEMENT}

All datasets generated for this study are included in the article/supplementary material.

\section{ETHICS STATEMENT}

The study has been approved by the Ethics committee in Freiburg (Number 235/15). All analyzes were performed with written informed consent of the patient, after ethics approval and in accordance to the Declaration of Helsinki.

\section{AUTHOR CONTRIBUTIONS}

FS and DK contributed conception and design of the study, they also wrote the initial manuscript draft. NI and TH performed part of the diagnostics and wrote sections of the manuscript. FS, MM, and DK cared for the patient, performed part of the diagnostics, and interpreted the results. LB-T interpreted the data and revised the manuscript critically for important intellectual content. All authors contributed to manuscript revision, read and approved the submitted version.

\section{FUNDING}

DK received honoraria from Amryt Pharma and Rheacell GmbH. FS received honoraria from Pfizer, Novartis and Amryt Pharma.

\section{ACKNOWLEDGMENTS}

We thank the patient. In addition, the excellent technical support by Kaethe Thoma, Ioannis Athanasiou, and Annegret Bedorf is gratefully acknowledged.

5. Krain LS, Bierman SM. Pemphigus vulgaris and internal malignancy. Cancer. (1974) 33:1091-9. doi: 10.1002/1097-0142(197404)33:4\&lt;1091::AIDCNCR2820330430\&gt;3.0.CO;2-Y

6. David M, Feuerman EJ. Induction of pemphigus by X-ray irradiation. Clin Exp Dermatol. (1987) 12:197-9. doi: 10.1111/j.1365-2230.1987. tb01894.x

7. Hunziker T, Zala L, Krebs A. [Roentgen ray-induced pemphigus vulgaris]. Hautarzt $Z$ Dermatol Venerol Verwandte Geb. (1988) 39:308-10.

8. Girolomoni G, Mazzone E, Zambruno G. Pemphigus vulgaris following cobalt therapy for bronchial carcinoma. Dermatologica. (1989) 178:37-8. doi: 10.1159/000248384

9. Low GJ, Keeling JH. Ionizing radiation-induced pemphigus. Case presentations and literature review. Arch Dermatol. (1990) 126:1319-23. doi: 10.1001/archderm.126.10.1319 
10. Delaporte E, Piette F, Bergoend H. [Pemphigus vulgaris induced by radiotherapy]. Ann Dermatol Venereol. (1991) 118:447-51.

11. Krauze E, Wygledowska-Kania M, Kaminska-Budzinska G, Lis A, BrzezinskaWcislo L. [Radiotherapy induced pemphigus vulgaris]. Ann Dermatol Venereol. (2003) 130:549-50.

12. Orion E, Matz H, Wolf R. Pemphigus vulgaris induced by radiotherapy. J Eur Acad Dermatol Venereol. (2004) 18:508-9. doi: 10.1111/j.1468-3083.2004.00952.x

13. Mseddi M, Bouassida S, Khemakhem M, Marrekchi S, Abdelmaksoud W, Hadjtaieb $\mathrm{H}$, et al. [Radiotherapy-induced pemphigus: a case report]. Cancer Radiother J Soc Francaise Radiother Oncol. (2005) 9:96-8. doi: 10.1016/j.canrad.2004.10.007

14. Robbins AC, Lazarova Z, Janson MM, Fairley JA. Pemphigus vulgaris presenting in a radiation portal. J Am Acad Dermatol. (2007) 56:S82-85. doi: 10.1016/j.jaad.2006.10.956

15. Saint-Jean M, Quéreux G, Peuvrel P, Dréno B. [Post-radiotherapy erosive lesion]. Ann Dermatol Venereol. (2008) 135:780-2. doi: 10.1016/j.annder.2008.03.009

16. Bar-Sela G, Baum S, Trau H, Kuten A. Pemphigus vulgaris of the larynx and upper gastro-intestinal tract induced by radiotherapy. Acta Oncol Stockh Swed. (2008) 47:324-326. doi: 10.1080/02841860701 558831

17. Vigna-Taglianti R, Russi EG, Denaro N, Numico G, Brizio R. Radiationinduced pemphigus vulgaris of the breast. Cancer/Radiothér. (2011) 15:334-7. doi: 10.1016/j.canrad.2011.01.006

18. Badri T, Hammami H, Lachkham A, Benmously-Mlika R, Mokhtar I, Fenniche S. Radiotherapy-induced pemphigus vulgaris with autoantibodies targeting a $110 \mathrm{kDa}$ epidermal antigen. Int J Dermatol. (2011) 50:1475-9. doi: 10.1111/j.1365-4632.2011.04889.x

19. Jang HW, Chun SH, Lee JM, Jeon J, Hashimoto T, Kim I-H. Radiotherapy-induced pemphigus vulgaris. J Dermatol. (2014) 41:851-2. doi: $10.1111 / 1346-8138.12582$

20. Thimon S, Machet L, Machet M-C, Samimi M, Maruani A. Pemphigus induced by radiotherapy for breast cancer: clinical, immunological and histological features of one case with antidesmoglein immunostaining. Eur J Dermatol. (2014) 24:119-20. doi: 10.1684/ejd. 2013.2239

21. Tang HKC, Lee DYH, Thompson I, Ingram JR, Stone N, Patel GK. Delayed and localized pemphigus vulgaris after breast cancer radiotherapy. Breast $J$. (2017) 23:747-9. doi: 10.1111/tbj.12910

22. Shon W, Wada DA, Kalaaji AN. Radiation-induced pemphigus or pemphigoid disease in 3 patients with distinct underlying malignancies. Cutis. (2016) 97:219-22.

23. O'Leary B, Alarcon L, Mallon E, Kirby A. Radiotherapy-associated pemphigus - a rare cause of grade 4 skin toxicity. Clin Oncol. (2017) 29:e50. doi: 10.1016/j.clon.2016.08.013

24. Tagami H, Imamura S, Noguchi S, Nishitani H. Coexistence of peculiar pemphigus, myasthenia gravis and malignant thymoma. Dermatologica. (1976) 152:181-90. doi: 10.1159/000251246

25. Ambay A, Stratman E. Ionizing radiation-induced pemphigus foliaceus. J Am Acad Dermatol. (2006) 54:251-2. doi: 10.1016/j.jaad.2005.12.024

26. Cianchini G, Lembo L, Colonna L, Puddu P. Pemphigus foliaceus induced by radiotherapy and responsive to dapsone. J Dermatol Treat. (2006) 17:244-6. doi: 10.1080/09546630600921197

27. Kikuchi K, Inokuma D, Moriuchi R, Koguchi-Yoshioka H, Yasui C, Shimizu S. Exacerbation of pemphigus foliaceus after electron-beam radiation. Acta Derm Venereol. (2014) 94:729-30. doi: 10.2340/0001 5555-1811

28. Inadomi T. A case of pemphigus foliaceus aggravated in an irradiated area by radiotherapy against breast cancer. Indian J Dermatol. (2015) 60:93-4. doi: 10.4103/0019-5154.147818

29. Liebman TN, Lieberman MR, Burris K. Pemphigus foliaceus exacerbated by radiation, in association with myasthenia gravis. Dermatol Online J. (2016) 22:13030/qt50p1246h.

30. Criado PR, Apparecida CD, Criado RFJ, Etcheverria ICR, Umeda LM, Landman G. Radiotherapy-induced Pemphigus Foliaceous: a rare adverse effect of breast cancer therapy. Int J Dermatol. (2018) 57:e165-7. doi: $10.1111 /$ ijd.14248
31. Sugi T, Hashimoto T, Hibi T, Nishikawa T. Production of human monoclonal anti-basement membrane zone. (BMZ) antibodies from a patient with bullous pemphigoid. (BP) by Epstein-Barr virus transformation. Analyses of the heterogeneity of anti-BMZ antibodies in BP sera using them. J Clin Invest. (1989) 84:1050-5. doi: 10.1172/JCI 114266

32. Hashimoto T, Ogawa MM, Konohana A, Nishikawa T. Detection of pemphigus vulgaris and pemphigus foliaceus antigens by immunoblot analysis using different antigen sources. J Invest Dermatol. (1990) 94:327-31. doi: 10.1111/1523-1747.ep12874456

33. Matsumura K, Amagai M, Nishikawa T, Hashimoto T. The majority of bullous pemphigoid and herpes gestationis serum samples react with the NC16a domain of the $180-\mathrm{kDa}$ bullous pemphigoid antigen. Arch Dermatol Res. (1996) 288:507-9. doi: 10.1007/ BF02505245

34. Nie Z, Hashimoto T. IgA antibodies of cicatricial pemphigoid sera specifically react with C-terminus of BP180. J Invest Dermatol. (1999) 112:254-5. doi: 10.1046/j.1523-1747.1999.00501.x

35. Ishii $\mathrm{N}$, Ohyama $\mathrm{B}$, Yamaguchi Z, Hashimoto $\mathrm{T}$. IgA autoantibodies against the NC16a domain of BP180 but not 120-kDa LAD-1 detected in a patient with linear IgA disease. Br J Dermatol. (2008) 158:1151-3. doi: 10.1111/j.1365-2133.2008.08492.x

36. Ishii $\mathrm{N}$, Yoshida $\mathrm{M}$, Hisamatsu $\mathrm{Y}$, Ishida-Yamamoto A, Nakane $H$, Iizuka $\mathrm{H}$, et al. Epidermolysis bullosa acquisita sera react with distinct epitopes on the NC1 and NC2 domains of type VII collagen: study using immunoblotting of domain-specific recombinant proteins and postembedding immunoelectron microscopy. Br J Dermatol. (2004) 150:84351. doi: 10.1111/j.1365-2133.2004.05933.x

37. Hisamatsu Y, Nishiyama T, Amano S, Matsui C, Ghohestani R, Hashimoto $\mathrm{T}$. Usefulness of immunoblotting using purified laminin 5 in the diagnosis of anti-laminin 5 cicatricial pemphigoid. J Dermatol Sci. (2003) 33:113-9. doi: 10.1016/S0923-1811(03)00158-0

38. Ishii N, Teye K, Fukuda S, Uehara R, Hachiya T, Koga H, et al. Antidesmocollin autoantibodies in nonclassical pemphigus. Br J Dermatol. (2015) 173:59-68. doi: 10.1111/bjd.13711

39. Amagai M, Komai A, Hashimoto T, Shirakata Y, Hashimoto K, Yamada $\mathrm{T}$, et al. Usefulness of enzyme-linked immunosorbent assay using recombinant desmogleins 1 and 3 for serodiagnosis of pemphigus. Br J Dermatol. (1999) 140:351-7. doi: 10.1046/j.1365-2133.1999. 02752.x

40. De Cicco L, Bracelli S. Pemphigus Vulgaris and Radiotherapy. Clin Oncol R Coll Radiol G B. (2018) 30:e38. doi: 10.1016/j.clon.2017. 10.011

41. Chen DM, Odueyungbo A, Csinady E, Gearhart L, Lehane P, Cheu M, et al. Rituximab is an effective treatment in patients with pemphigus vulgaris and demonstrates a steroid-sparing effect. Br J Dermatol. (2019). doi: 10.1111/bjd.18482. [Epub ahead of print].

42. Mai Y, Nishie W, Sato K, Hotta M, Izumi K, Ito K, et al. Bullous pemphigoid triggered by thermal burn under medication with a dipeptidyl peptidase-IV inhibitor: a case report and review of the literature. Front Immunol. (2018) 9:542. doi: 10.3389/fimmu.2018.00542

43. Hirotsu K, Chiou AS, Chiang A, Kim J, Kwong BY, Pugliese S. Localized bullous pemphigoid in a melanoma patient with dual exposure to $\mathrm{PD}-1$ checkpoint inhibition and radiation therapy. JAAD Case Rep. (2017) 3:404-6. doi: 10.1016/j.jdcr.2017.06.004

44. Nguyen T, Kwan JM, Ahmed AR. Relationship between radiation therapy and bullous pemphigoid. Dermatol Basel Switz. (2014) 229:88-96. doi: $10.1159 / 000362208$

45. Dar TB, Henson RM, Shiao SL. Targeting innate immunity to enhance the efficacy of radiation therapy. Front Immunol. (2018) 9:3077. doi: $10.3389 /$ fimmu.2018.03077

46. Hammers CM, Stanley JR. Mechanisms of disease: pemphigus and bullous pemphigoid. Annu Rev Pathol. (2016) 11:175-97. doi: 10.1146/annurev-pathol-012615-044313

47. Li J-Y, Lu Y-H, Zhang L-W, Zhou P-M, Chen T. Increased serum high mobility group box 1. (HMGB1) concentration and the altered expression of HMGB1 and its receptor advanced glycation endproducts in pemphigus. Ann Dermatol. (2017) 29:121-3. doi: 10.5021/ad.2017.29.1.121 
48. Lehmann PV, Forsthuber T, Miller A, Sercarz EE. Spreading of T-cell autoimmunity to cryptic determinants of an autoantigen. Nature. (1992) 358:155-7. doi: 10.1038/358155a0

49. Ruocco V, Brunetti G, Puca RV, Ruocco E. The immunocompromised district: a unifying concept for lymphoedematous, herpes-infected and otherwise damaged sites. J Eur Acad Dermatol Venereol. (2009) 23:1364-73. doi: 10.1111/j.1468-3083.2009.03345.x

50. Xiao S, Shterev ID, Zhang W, Young L, Shieh J-H, Moore M, van den Brink $\mathrm{M}$, et al. Sublethal total body irradiation causes long-term deficits in thymus function by reducing lymphoid progenitors. J Immunol Baltim Md 1950. (2017) 199:2701-12. doi: 10.4049/jimmunol.1600934
Conflict of Interest: The authors declare that the research was conducted in the absence of any commercial or financial relationships that could be construed as a potential conflict of interest.

Copyright (C) 2020 Schauer, Ishii, Mockenhaupt, Bruckner-Tuderman, Hashimoto and Kiritsi. This is an open-access article distributed under the terms of the Creative Commons Attribution License (CC BY). The use, distribution or reproduction in other forums is permitted, provided the original author(s) and the copyright owner(s) are credited and that the original publication in this journal is cited, in accordance with accepted academic practice. No use, distribution or reproduction is permitted which does not comply with these terms. 